92 Tropelías. Revista de Teoría de la Literatura y Literatura Comparada, 21 (2014)

José Luis Gómez Toré

\title{
EL ANIMAL DEL LLANTO: BESTIARIOS DE LA IMAGINACIÓN EN LA POESÍA DE ANTONIO GAMONEDA
}

\section{José Luis GÓMEZ TORÉ}

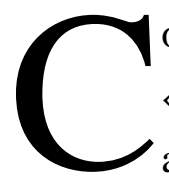

omo señala Miguel Casado, en la poesía de Antonio Gamoneda lo biográfico mantiene «constantemente activa la tensión fundamental entre autonomía del texto y referencia autobiográfica» ${ }^{1}$. Si su obra se nos ha vuelto imprescindible como uno de los jalones fundamentales de la poesía española contemporánea se debe en buena parte a esa sabia conciencia de una autonomía de la obra artística que no está dada de antemano sino que es conquistada en cada texto y se mantiene en preclario equilibrio entre la inmanencia de los signos y la sedimentación de materiales procedentes de la memoria. Contra la conciencia ingenua que reduce toda escritura a mímesis pero también contra la ingenuidad no menor de equiparar la autonomía de la obra artística a una creación ex nihilo, ha escrito Adorno «hasta la obra más sublime adopta una posición determinada frente a la realidad empírica cuando se escapa de su hechizo, no de una vez para siempre, sino una y otra vez $[\ldots] »^{2}$. La inteligencia poética de la escritura de Gamoneda se sitúa así en la dialéctica fecunda entre lo mimético y lo simbólico, entre la inmanencia del texto y la vivencia de la escritura como emanación de la vida, un juego de tensiones y conciliaciones que nos hacen transitar a los lectores por un paisaje a la vez familiar y extraño. Gamoneda re-crea lo vivido en el sentido etimológico del verbo: la experiencia tamizada, transformada en la escritura, se transforma en otra realidad, en una realidad artística, que ya no es espejo de la experiencia pero que se nutre del humus de la memoria tanto consciente como inconsciente.

Si ignoramos esta peculiaridad de su mirada poética, que nos la hace tan contemporánea, cualquier lectura crítica de los temas y motivos de la poesía de Gamoneda resulta errada. Así, a la hora de analizar las presencias, casi obsesivas, del mundo animal en los libros del poeta, no tendremos más remedio que tener en cuenta esa posición, incómoda para el crítico pero fecunda para el poema, en la que lo real se vuelve simbólico y lo simbólico se transforma en una realidad independiente, que reclama su autonomía frente a lo vivido.

Libros como El cuerpo de los símbolos y en especial sus memorias de infancia, Un armario lleno de sombra, nos muestran cómo, a menudo, las imágenes de Gamoneda que se nos antojan más

\footnotetext{
${ }^{1}$ M. Casado (2004), «El curso de la edad», A. Gamoneda, Esta luz. Poesía reunida (1947-2004), 579.

2 Th. W. Adorno (2004), Teoría estética. Obra completa, 15.
} 
irracionales, más creación pura de la imaginación, tienen un asidero en la experiencia. Así, en el primero de los libros citados, el poeta nos explica:

La realidad es simbólica y yo soy un poeta realista porque los símbolos están verdadera y físicamente en mi vida $[\ldots .$.$] Cuando digo "esta casa estuvo dedicada a la labranza y a la muerte", hay aparición de$ símbolos, sí, pero sucede, además, que esta casa estuvo realmente dedicada a la labranza y a la muerte [...]

Cuando digo: "Hay azúcar debajo de la noche, hay la mentira como un corazón clandestino debajo de las alfombras de la muerte", yo sé, apenas lo he dicho, que estoy rescatando materialidades de mi infancia, cuerpos reconocibles: yo robaba el azúcar, jugaba con las alfombras y mi madre me predicaba con la muerte. ${ }^{3}$

¿De dónde surgen las figuras animales que pueblan no pocas páginas del poeta? Basta con leer Un armario lleno de sombra para comprobar que la convivencia con el mundo animal formaba parte de la experiencia habitual del niño que fue Antonio Gamoneda. El León de los años cuarenta y cincuenta, y más para un habitante de su extrarradio, ofrecía un paisaje en el que se entremezclaban rasgos de lo rural y de lo urbano. Gallinas, perros callejeros, carromatos arrastrados por bueyes o caballos, asnos usados como animales de carga, bestias sacrificadas en la casa para consumo humano o expuestos en el mercado o la carnicería, el zureo de las palomas en el desván de una casa... todo eso son presencias familiares para el niño que se abre al mundo en un panorama, el del primer franquismo y la primera posguerra, dominado por ese clima que el propio Gamoneda ha denominado «cultura del hambre» $\mathrm{o}$ «cultura de la pobreza» ${ }^{4}$. La fascinación que los niños suelen sentir por el mundo animal, presencia frecuente en los relatos infantiles, se entremezcla, en la vivencia personal del futuro escritor, con una experiencia nada idealizada en la que el animal forma parte del entramado de la subsistencia humana, del mundo de la comida y del trabajo.

En un artículo incluido en El cuerpo de los símbolos, «Los caballos inmóviles de Jorge Guillén» ${ }^{5}$, al comentar un soneto del poeta del 27, Gamoneda señala su distancia entre la visión literaria de Guillén y su propia mirada sobre el caballo (que es, sin duda, una de las presencias animales más repetidas en sus poemas): «Mi núcleo poemático no abarca más allá de la condición inmóvil y peluda, y me acompaña el triste conocimiento de que el destino de las bestias es la carnicería» ${ }^{6}$. La contemplación estética no llega a borrar la realidad precaria de los cuerpos, la menesterosidad de seres amenazados, como el propio yo que escribe, por la muerte.

De hecho, un motivo recurrente en sus memorias de infancia es el sacrificio del animal. En $U n$ armario lleno de sombra, el niño no es ajeno a ese acto de violencia aunque no participe directamente en ella: «No volví a subir al desván con don Ángel, pero aquella noche chupé concienzudamente un hueso. Yo sabía que era un hueso de la paloma grande» ${ }^{7}$. «El cordero desapareció de casa. Si preguntaba por él me contestaba con evasivas. Supongo que yo también comí de la carne de Tiquín» ${ }^{8}$. La muerte del cordero, con el que jugaba el pequeño Antonio, aparece reflejada asimismo en uno de

\footnotetext{
${ }^{3}$ A. Gamoneda (1997), El cuerpo de los símbolos, 27.

${ }^{4}$ Id. (2009), Un armario lleno de sombra, 52.

${ }^{5}$ Id., El cuerpo de los símbolos, op. cit., 155-158.

${ }^{6}$ Ibid., 158.

${ }^{7}$ A. Gamoneda, Un armario lleno de sombra, op. cit., 91.

${ }^{8}$ Ibid., 78.
} 
los poemas de Lápidas, cuyo final nos sitúa muy lejos del topos romántico de la infancia como Edad de Oro: «Finalmente el cordero fue enviado a la carnicería, y yo aprendí que quienes me amaban también podían decidir sobre la administración de la muerte» ${ }^{9}$. Sin desdeñar el anclaje del texto en la experiencia, resultaría, sin embargo, empobrecedor limitarse a una lectura puramente literal de lo narrado. Como nos dice el inicio del poema, «Eran días atravesados por los símbolos». El buey desollado de Rembrandt o la reinterpretación posterior de Soutine no son simplemente naturalezas muertas, copias de la realidad, sino que en el lienzo alcanzan un espesor simbólico, una entidad propia. De igual manera, en el texto de Gamoneda no nos encontramos simplemente ante la evocación de un recuerdo infantil. En el marco del poema, este episodio apunta hacia una significación nueva, que en el caso concreto de este texto, anuda no pocas de las obsesiones del poeta: la muerte como horizonte de toda experiencia vital, la violencia latente en la historia humana así como una visión materialista de la existencia, que lleva a abolir la distancia idealista entre el ser humano y el animal pues ambos son seres corporales, hechos de materia y de tiempo, y por tanto mortales.

Otro motivo que se repite en las memorias es la mirada enigmática del animal ya muerto o en el umbral de la muerte:

Don Ángel cerró la mano izquierda y, con la paloma prisionera, deslizó la derecha bajo sus alas y apretó fuerte y largo hasta parar su corazón. La paloma abrió dos veces el pico con una amplitud desesperada; luego dejó caer la cabeza sobre los nudillos replegados. Uno de sus ojos, cristalizado, la córnea roja rodeando la pupila inmóvil, no cesaba de mirarme ${ }^{10}$.

Había un resplandor en torno de sus ojos, que habrían de ser de cristal y que, en mi visión ahora recuperada, no se corresponden con la mirada de un caballo: sobre la pupila inmóvil, empapando la córnea, yo veo extenderse un reguerillo de lágrimas ${ }^{11}$.

Dimos unos pasos y yo volví la cabeza para contemplar la agonía del asno. Volvía los ojos hasta dejar ver sólo la blancura esclerótica ${ }^{12}$.

La mirada blanca del asno contemplada por el niño revela el más que probable origen de una de las imágenes que se repite en su poesía: «blancos en la demencia como los ojos de los asnos en el instante de la muerte ${ }^{13}$, «jóvenes amnistiados por el agua bajo la mirada blanca de los asnos» ${ }^{14}$. Más determinante, sin embargo, que el sustrato biográfico es la reiterada presencia de la mirada como un núcleo temático y simbólico de la escritura gamonediana. Ya desde Homero mirar y ser mirado es uno de los signos de la vida: en la Ilíada la oscuridad que cae sobre los ojos es una insistente metáfora del morir. El niño, el poeta adulto que se asoma al ojo del animal parece querer ser visto desde ese otro lado, atisbar el secreto de la muerte. Pero al mismo tiempo, el hecho de buscar la mirada del animal supone una suerte de identificación con él: la mirada mutua de reconocimiento parece acercar al animal

\footnotetext{
${ }^{9}$ A partir de ahora, todas las citas literales de los poemas de Gamoneda se harán en referencia a la última edición de su poesía completa, Esta luz, op. cit, 258.

${ }^{10}$ Id., Un armario lleno de sombra, op. cit., 91.

${ }^{11}$ Ibid., 115.

12 Ibid., 144.

${ }^{13}$ A. Gamoneda, Esta luz., op. cit., 231.

${ }^{14}$ Ibid., 260.
} 
a la mirada humana, en un intento de humanizarlo que, sin embargo, conserva el carácter enigmático de la bestia, del ser que vive más allá del lenguaje y cuya mirada resulta así en el fondo indescifrable. ¿La mirada de la paloma muerta es una acusación o solo el vacío indiferente de la nada? ¿Hacia donde dirige sus ojos el asno en su agonía? ¿Por qué el poeta adulto recupera la imagen de un ojo de cristal en un caballo disecado como si fuera algo más que la huella de una efímera fantasía infantil? Una y otra vez, el animal parece remitir a la mudez de un mundo que no habla ningún lenguaje humano, al estupor ante el hecho de existir tan enigmático como la posibilidad de no existir.

Carmen Palomo, al comentar el breve texto de Gamoneda sobre Guillén, se atreve a contradecir al maestro y, al señalar que todos los caballos en la poesía del primero parecen estar marcados por la muerte, asegura: «por caminos diferentes a los transitados por los caballos de Guillén, los de Gamoneda acceden a ámbitos significativos inmersos en lo mítico, en lo sobrenatural» ${ }^{15}$. Acierta Palomo plenamente en la dimensión mítica que adquieren los animales (y no solo los caballos) en la poesía de Antonio Gamoneda. Aunque su presencia se alimente de vivencias biográficas, al formar parte del poema se vuelven presencias enigmáticas separadas de un contexto que, en gran parte, se nos hurta. Sin embargo, si bien la referencia al mito me parece del todo acertada, creo que habría que matizar la identificación entre lo mítico y lo sobrenatural que parece desprenderse del interesante artículo de esta investigadora.

Paradójicamente, los animales acceden al mito no por su carácter sobrenatural, sino por su pura realidad inmanente, lejos de cualquier trascendencia. Gamoneda ha dado una definición muy personal de la poesía como «arte de la memoria en la perspectiva de la muerte» ${ }^{16}$. Al mirarse en el espejo de la nada, toda vida se vuelve enigmática. Como sobre un diorama en un teatro, el animal y el hombre se recortan como sombras fantasmales al proyectarse sobre el telón de fondo de la inexistencia. En pocas aventuras poéticas contemporáneas se percibe tanto la experiencia de lo sagrado como en la escritura de Gamoneda pero tampoco resulta fácil encontrar una lírica tan marcada por la total ausencia de trascendencia religiosa ${ }^{17}$. La imaginación encuentra en el animal una encarnación privilegiada del enigma de lo vivo, que lleva en sus entrañas las semillas de la muerte. A este respecto, quizá resulte interesante recordar que en numerosos pueblos, las divinidades que pueblan el mundo sobrenatural tienen forma de animales. Sin embargo, los animales son, en Gamoneda, figuras de lo sagrado no porque afirmen, sino precisamente, porque niegan toda trascendencia.

De esta manera, nos volvemos a encontrar con la necesidad de mantener abierta siempre, incluso ante los motivos de clara procedencia biográfica, una lectura simbólica. Y es que en Gamoneda hay también un vínculo entre el horizonte ineludible de la muerte y su vivencia del símbolo. El escritor ha

\footnotetext{
${ }^{15}$ C. Palomo (2008), «Caballos. Pequeña refutación al autor», Ínsula, 19.

${ }^{16}$ A. Gamoneda, El cuerpo de los símbolos, op. cit., 26.

${ }^{17}$ Escribe el poeta «La palabra "trascendencia" me da mucho miedo: no sé manejarla. En mi trabajo poético puede haber contaminación del lenguaje religioso, pero no convicciones. No soy hombre religioso aunque puede estar habitado por voces religiosas», (A. Gamoneda, El cuerpo de los símbolos, op. cit., 173). En anteriores trabajos me he ocupado de esta sacralidad inmanente en la obra de Gamoneda (J. L. Gómez Toré (2005), «Antonio Gamoneda: palabra corporal, poesía del cuerpo», Cuadernos del Minotauro, 89-97, y J. L. Gómez Toré (2006), «Un instante sin límites. Memoria y elegía en la escritura de Antonio Gamoneda», Quimera, 40-45.
} 
hablado de cómo su escritura se va poblando de imágenes «que no se sabe lo que simbolizan» y cómo estos símbolos incluso «pueden simbolizarse a sí mismos» ${ }^{18}$. Se trata de una vivencia del símbolo que más cercana a la visión de lo alegórico propuesta por Walter Benjamin y reelaborada por Paul de Man que al simbolismo tradicional, todavía presente, aunque secularizado, en buena parte de la tradición heredera del Romanticismo ${ }^{19}$. Los símbolos de Gamoneda, como los de buena parte de la escritura contemporánea, parecen haber perdido la confianza en formar parte de un idioma secreto, de una red de correspondencias a través de las cuales se revela una realidad superior. Los símbolos no son ya sinécdoques de la totalidad. Si la realidad es simbólica, no es porque en ella pueda leerse la escritura de un Creador, sino porque la visión del mundo ha estallado en una pluralidad de fragmentos que ya no se refieren a un todo. Así, los símbolos del poema se multiplican, se persiguen entre sí, sin poder apresar una totalidad siempre preterida: reenvían constantemente unos a otros para leerse entre sí, como consecuencia del descrédito de la metáfora del mundo como libro. La poesía ya no es el lenguaje secreto que revela las huellas de la creación. Leer, y también escribir, se convierte así menos en una búsqueda del sentido que en una creación de sentido. Esta creación no está, sin embargo, exenta de angustia porque los significados que teje la palabra poética nacen conscientes de su precariedad. Nada más surgir, en cualquier momento pueden volver a disolverse en el sinsentido que intentan negar ( «Bajo las águilas silenciosas, la inmensidad carece de significado» ${ }^{20}$, escribe Gamoneda en el poema que abre su Libro del frío). Sin embargo, paradójicamente esa pobreza ontológica de los símbolos da cuenta de su riqueza: si el símbolo ya no es el territorio de la esencia, si ya no es la red que apresa el misterio del mundo, al mismo tiempo esta carencia libera a los símbolos para no fijarse en una lectura unívoca.

En este sentido, conviene no interpretar la presencia mítica de los animales en su poesía como si nos encontráramos ante un bestiario medieval, en el que cada criatura lleva asociada una significación precisa que responde a los códigos más o menos estrictos de la tradición. Aunque es posible encontrar ciertas constantes en el uso de los símbolos teriomorfos, como los denomina Durand ${ }^{21}$, dichas constantes no son categorías estáticas sino que responden al dinamismo de cada texto, a la tensión de fuerzas que se establece entre los distintos símbolos convocados en el poema. Así, si bien la frecuente utilización por parte de Gamoneda del genérico «animal» (en singular o en plural) parece invitar a una lectura más directamente simbólica que la presencia de animales concretos (como si la concreción genérica, el nombre de una especie, invitara a una posible fuente de experiencia), sin embargo ello dista mucho de ser una ley fija: la alusión a palomas, gavilanes, perros, caballos, reses... no tiene por

\footnotetext{
${ }^{18}$ M. Agudo, (ed.) (2006), «Somos únicamente palabras. Antonio Gamoneda en conversación», Quimera, 30.

${ }^{19}$ La imprescindible reflexión de Benjamin sobre la alegoría (W. Benjamin (2007), Obras: libro I/ volumen 1. El concepto de crítica de arte en el Romanticismo alemán. «Las afinidades electivas» de Goethe. El origen del «Trauerspiel», 375-415) encuentra un interesante eco en los análisis de Paul de Man (1991) (Visión y ceguera: Ensayos sobre la retórica de la crítica contemporánea, 207-231) y ambas lecturas parecen situarse en un horizonte próximo al retorno del lenguaje que plantea M. Foucault (2009) en Las palabras y las cosas. Una arqueología de las ciencias humanas. Asimismo, Adorno ha cuestionado la vinculación entre la obra de arte y el simbolismo tradicional (Th. W. Adorno, Teoría estética, op. cit.).

${ }^{20}$ A. Gamoneda, Esta luz, op. cit., 307.

${ }^{21}$ G. Durand (2005), Las estructuras antropológicas de lo imaginario. Introducción a la arquetipología general, 73-93.
} 
qué suponer un referente concreto e, incluso, cuando creemos encontrarnos con el origen de una imagen en una determinada experiencia, lo cierto es que la propia escritura nos impele a leer dichas presencias dentro del contexto creado por el poema, más que en la realidad extralingüística. Por otra parte, nunca estamos seguros de que el genérico «animal» no tenga en determinados poemas un referente biográfico: sin embargo, el origen de esos símbolos animales no deja de ser la mayor parte de las veces un aspecto muy secundario en la lectura. Lo importante para el lector no es tanto de dónde procedan las imágenes, sino cómo esas imágenes se entrelazan para dar vida al texto.

Aunque en Sublevación inmóvil y Blues castellano, no faltan las referencias al reino animal (que generalmente se plasma en animales concretos, aunque dicha concreción sea, por ejemplo, el también genérico «pájaros»), es a partir de los textos escritos en torno a los años setenta y ochenta (Lápidas, Descripción de la mentira, Libro del frío) cuando la presencia animal se vuelve una suerte de obsesión. La palabra «animal» o «animales» nos asalta con cada vez mayor frecuencia, normalmente acompañada de un complemento nominal que, si bien introduce cierta concreción, rara vez apunta hacia una descripción física o denotativa, sino que suele introducir valores emocionales y metafóricos, que acentúan el extrañamiento ante tales presencias. Así, en Descripción de la mentira, encontramos a alguien que entra «en la habitación como un animal resplandeciente» ${ }^{22}$, se nos dice que la crueldad nos hace semejantes a «animales sagrados» ${ }^{23}$, se alude a «la grasa de los animales torturados» ${ }^{24} \mathrm{y}$ encontramos imágenes tan inquietantes como «mis animales desconocen la delgadez de tus cuchillos» ${ }^{25}$. Hay también «un animal invisible» ${ }^{26}$, un «animal que llora» ${ }^{27}$, «animales tan antiguos como mi corazón» ${ }^{28}$, «animales portadores de calcio» ${ }^{29}$, «animales sosegados ${ }^{30} \ldots$

De momento, nos interesa detenernos en expresiones como «mis animales» $\mathrm{u}$ otras semejantes: «El miedo ejerce de pastor, pero no sabes más de ti que un animal absorto sobre el agua» ${ }^{31}$. En imágenes como estas parece insinuarse una vinculación entre esas presencias animales y la voz que habla, como si esas figuras revelaran algo sobre la propia interioridad. Jung ha escrito, a propósito del simbolismo del caballo en la mitología y el folclore, que esta criatura «en tanto que animal encarna la psique no humana, lo subhumano, el animal que hay en nosotros $\mathrm{y}$, por ello, el psiquismo inconsciente $»^{32}$. De igual manera, en numerosas tradiciones religiosas ${ }^{33}$ y de manera eminente en la iconografía cristiana medieval, los animales, aunque pueden simbolizar las virtudes, representan más a menudo las pasiones, el mundo del pecado, el riesgo de que el alma humana recaiga en lo instintivo,

\footnotetext{
${ }^{22}$ A. Gamoneda, Esta luz, op. cit., 177.

${ }^{23}$ Ibid., 178.

${ }^{24}$ Ibid., 197.

${ }^{25}$ Ibid., 187.

${ }^{26}$ Ibid., 195.

${ }^{27}$ Ibid., 198.

${ }^{28}$ Ibid., 201.

${ }^{29}$ Ibid., 205.

${ }^{30}$ Ibid., 207.

${ }^{31}$ Ibid., 220.

${ }^{32}$ C. G. Jung (1992), Los complejos y el inconsciente, 348.

33 J. E. Cirlot (2000), Diccionario de símbolos, 82-85; J. Chevalier y A. Gheerbrant (1999), Diccionario de los símbolos, 102-105.
} 
en la carne mortal y sus apetencias ${ }^{34}$. La poesía de Gamoneda, que prescinde de ese horizonte de trascendencia, da la impresión de querer subvertir la distancia idealista que el imaginario cristiano ha puesto entre el animal y el ser humano: al dejar emerger el animal que hay en nosotros, señala un común destino entre el animal y el hombre, el de ser criaturas materiales, que no tienen cuerpo sino que son cuerpo, y por tanto también criaturas mortales. El animal parece asociarse (y ello se muestra con mayor claridad cuando se le denomina con el nombre de su especie concreta) con la precariedad de lo existente siempre al borde de la inexistencia. La figura animal se muestra así como un símbolo privilegiado para hablarnos de la piedad que despierta la carne amenazada por el dolor, por la enfermedad, por la muerte, que es, sin embargo, también carne deseante, carne que sabe asimismo del placer, de precarias alegrías (una tonalidad emocional que tiñe buena parte de los poemas de Libro del frío y de Arden las pérdidas y, que en una clave más política, de solidaridad humana, se nos muestra en Blues castellano). Quizá una de las imágenes de menesterosidad más emocionantes es la que aparece en el poema «Malos recuerdos» ${ }^{35}$ de Blues castellano, a cuya anécdota de sorprendente crudeza también se refiere Gamoneda en sus memorias infantiles ${ }^{36}$. La evocación avergonzada de la crueldad infantil pone entre paréntesis la humanidad del que habla y humaniza al mismo tiempo a la bestia, hermanada con las otras víctimas de la inconsciencia infantil, el soldado y su madre. Solo la vergüenza, la consciencia de la incapacidad de deshacer el mal, permite al adulto recuperar la certeza de la humanidad desde la conciencia ética del arrepentimiento.

No obstante, junto a este aspecto del animal como carne amenazada, frágil, conviene retener otro elemento que ya aparece en el simbolismo tradicional: su vínculo con lo instintivo, con aquello que escapa o puede escapar al dominio de la razón humana. En la iconografía cristiana lo animal y lo demoníaco están en ocasiones muy próximos si bien hay también animales como el cordero o la paloma que se presentan, por el contrario, como emblemas de la santidad. Dicha iconografía tenía sin duda muy presente la frecuente asociación, en el mundo pagano, entre el dios y el animal. Dioses y animales forman parte, desde esta perspectiva, del territorio de lo no-humano, de las potencias de una naturaleza cuyas fuerzas, a menudo hostiles, parecen escapar al control del hombre (recordemos, al respecto, los animales ponzoñosos del Libro de los venenos ${ }^{37}$ ). Como nos recuerda Broch en La muerte de Virgilio, el dios y el animal están más allá del lenguaje: «entre el mutismo del animal y el dios está la palabra humana» ${ }^{38}$. Señalan así hacia la vivencia ambivalente de lo sagrado, fascinante y terrible a un tiempo ${ }^{39}$. Con todo, esa ambivalencia se resuelve las más de las veces en el predominio de lo terrible: la existencia, desprovista de todo consuelo religioso, de los nombres divinos que vuelven soportable el territorio del mito, aparece atravesada por el miedo. «En el principio era el delirio», escribe María

\footnotetext{
${ }^{34}$ L. Monreal y Tejada (2000), Iconografía del Cristianismo, 454.

${ }^{35}$ A. Gamoneda, Esta luz, op. cit., 102-103.

${ }^{36}$ Id., Un armario lleno de sombra, op. cit., 208-210.

${ }^{37}$ Id. (1997), Libro de los venenos.

${ }^{38}$ H. Broch (2007), La muerte de Virgilio, 501.

${ }^{39}$ R. Otto (2005), Lo santo. Lo racional y lo irracional en la idea de Dios, 21-35; M. Zambrano (2005), El hombre y lo divino, 29-31.
} 
Zambrano $^{40}$ al referirse a esa vivencia de lo sagrado anterior a los dioses, una vivencia que se nos antoja muy próxima a la que sobreviene tras la experiencia de la muerte de Dios (escribe el poeta en Libro del frío: «y cae Dios (máscara antigua; no de ese hueco de tu corazón sino del que hay delante de tu rostro)» ${ }^{41}$ ).

No es de extrañar, por tanto, que en la poesía de Gamoneda, las figuras animales se asocien con lo invisible. La invisibilidad del animal denuncia su parentesco con las corrientes subterráneas del inconsciente, de la naturaleza no domeñada en uno mismo, con las fuerzas ocultas del mundo natural que el yo siente actuantes tanto en el exterior como en su propia y desconocida interioridad. La naturaleza se convierte así en un territorio misterioso en el que se funden inextricablemente la muerte y la vida, la ternura y la violencia, la piedad y el miedo. El genérico «animal» parece aludir a ese carácter enigmático y por tanto ingobernable de dichas presencias mientras que el complemento nominal que suele acompañarle se nos muestra como un tímido intento de apresar el enigma. Así, el adjetivo «invisibles» («animales invisibles» ${ }^{42}$, «pájaros invisibles» ${ }^{43}$ ) en Descripción de la mentira nos sitúa en la perplejidad del yo lírico que siente cómo el misterio de la realidad se le escapa ya que lo real es también aquello que no se $\mathrm{ve}^{44}$. Si «la insistencia en el verbo ver» ${ }^{45}$, la importancia de la mirada es un rasgo central en la poesía de Gamoneda ${ }^{46}$, la confesión de la propia ceguera supone hacerse cargo, no de una imposible trascendencia, sino de que la realidad, aun en su inmanencia, escapa a nuestras redes conceptuales. Incluso nosotros mismos somos para nuestra conciencia un enigma. La naturaleza es así el reino de lo sagrado inmanente, de una sacralidad que no encierra ninguna promesa escatológica sino que, por el contrario, nos obliga a mirar cara a cara a la muerte como ley ineludible de la existencia. Los dioses que emergen de esa oscuridad indomeñable de lo sagrado, a menudo como figuras animales, son tan efímeros, tan mortales como la voz que los nombra.

En Lápidas, no faltan esas presencias animales enigmáticas que, como dioses o demonios o tal vez como víctimas propiciatorias, aparecen convocadas en el poema: «Todos los animales se reúnen en un gran gemido ${ }^{47}$, «asiste a la tortura de animales ciegos» ${ }^{48}, \ll \mathrm{El}$ animal oscuro viene en medio de vientos» ${ }^{49}$, «animales ciegos en la contemplación del rocío» ${ }^{50}$... Las encontramos también en Arden las pérdidas: «Las uñas de animales inexistentes arrancan nuestros ojos en los sueños» ${ }^{51}$, «la cirugía/

\footnotetext{
${ }^{40}$ M. Zambrano, El hombre y lo divino, op. cit., 31.

${ }^{41}$ A. Gamoneda, Esta luz, op. cit., 379.

42 Ibid., 195.

${ }^{43}$ Ibid., 201.

${ }^{44}$ Esta lectura simbólica de lo invisible es compatible con otra posible lectura, la que asocia la invisibilidad con lo desaparecido, con lo muerto (T. Blesa, 2008, «Sombras de luz», Ínsula, 18). Precisamente el hecho de que la vida esté indisolublemente anudada a la muerte es uno de los aspectos que más contribuye a que la realidad sea vivida como enigmática y que por tanto se imagine una profundidad invisible tras la visibilidad inverosímil de su superficie.

${ }^{45}$ M. Casado, «El curso de la edad», op. cit., loc. cit.

${ }^{46}$ E. Moga (2006), «Épica sensible. Saint-John Perse y Antonio Gamoneda», Quimera, 50-53.

${ }^{47}$ A. Gamoneda, Esta luz, op. cit., 240.

48 Ibid., 247.

${ }^{49}$ Ibid., 248

50 Ibid., 271.

${ }^{51}$ Ibid., 429.
} 
del animal lleno de sombra» ${ }^{52}$, «Un animal oculto en el crepúsculo me vigila y se apiada de mí» ${ }^{53}$... Entre ambos, Libro del frío, muestra una especial predilección por este simbolismo: «animales húmedos ${ }^{54}$, «Llegan los animales del silencio» ${ }^{55}$, «Un animal de luz cunde debajo de tu piel» ${ }^{56} \ldots$ En concreto, en este poemario, nos encontramos con distintas variaciones de una presencia enigmática, la de una suerte de encarnación de la tristeza: «El animal del llanto lame las sombras de tu madre y tú recuerdas otra edad ${ }^{57}, \ll \mathrm{El}$ animal que llora, ése estuvo en tu alma antes de ser amarillo» ${ }^{58}$, «Lame tu piel el animal del llanto» ${ }^{59}$. Volveremos a encontrar expresiones semejantes en Arden las pérdidas: «vi las huellas de los animales concebidos en el llanto» ${ }^{60}$, «Hay un caballo dentro de mis ojos y el padre de los que después aprendieron a llorar» ${ }^{61}$.

Resulta tentador interpretar este misterioso animal del llanto como una imagen de la depresión, de esas depresiones que el poeta, como nos recuerda en sus memorias ${ }^{62}$, ha padecido con frecuencia. Ello sería traicionar, sin embargo, el espesor enigmático con que se nos presentan estos poemas, la dirección que impone la propia escritura. Es probable que la tendencia a la depresión haya sido un elemento autobiográfico de peso en el nacimiento de estas imágenes (pero, ¿por qué no también las escenas de la posguerra del dolor de otros contempladas por el pequeño Antonio y rememoradas en Un armario lleno de sombra o el ojo falso del caballo que, al niño, se le presenta mojado por las lágrimas?). Con todo, lo determinante es cómo la escritura de Gamoneda, reelabore o no elementos biográficos, nos presenta sus imágenes liberadas de un contexto concreto. Así, estos animales que, en ocasiones no sabemos si lloran ellos mismos o provocan el llanto, se nos presentan a la vez como poderosos e inermes, como signos de esa visión trágica de la existencia que impregna toda la escritura de Antonio Gamoneda. El llanto evoca no solo la certeza, que recuerda a nuestros poetas barrocos, de que la vida está atravesada por principio a fin por la posibilidad del sufrimiento, sino que también (lo que es tal vez más importante) convierte la escritura en un ejercicio de piedad. La piedad por todo lo vivo, que surge de la conciencia de la propia precariedad, de lo vulnerable de todo cuerpo, es quizá el elemento ético central en toda la escritura de Gamoneda (una mirada compasiva y profundamente moral que nos obliga a no trazar líneas de ruptura entre la piedad por los oprimidos de Blues castellano y la obra posterior). El llanto es asimismo una imagen de la propia poesía: «El animal perfecto es feliz en los claustros y su lengua es melodiosa en el llanto» ${ }^{63}$. El poema, que paradójicamente es una fuente de placer (estético) también en la expresión del dolor, nos ofrece otra paradoja en su extraña manera de ejercer la compasión (compasión, en el mejor sentido, el etimológico «sentir-con», del término): si

\footnotetext{
52 Ibid., 439.

53 Ibid., 462.

${ }^{54}$ Ibid., 327.

55 Ibid., 362.

56 Ibid., 395.

${ }^{57}$ Ibid., 372.

${ }^{58}$ Ibid., 375.

${ }^{59}$ Ibid., 393.

${ }^{60}$ Ibid., 474.

${ }^{61}$ Ibid., 467.

${ }^{62}$ A. Gamoneda, Un armario lleno de sombra, op. cit., 173-174.

${ }^{63}$ Id., Esta luz, op. cit., 379.
} 
el poema se muestra inmisericorde al obligarnos a mirar cara a cara los signos de nuestra propia mortalidad, en el esfuerzo, sin embargo, por dejar que la experiencia del sufrimiento acceda a la palabra esboza un necesario gesto de piedad ante una realidad herida, constantemente amenazada.

Anteriormente, hacíamos referencia a la presencia de figuras animales nombradas con un mayor grado de concreción, no ya con el genérico «animal»o «bestia». Con mucho, las figuras animales más frecuentes en la poesía de Gamoneda son las aves, a menudo nombradas con el menos génerico «pájaros» pero no únicamente: encontramos así palomas, águilas, avefrías, gavilanes, tórtolas, ruiseñores, mirlos, zorzales, vencejos... La importancia del ave como símbolo radica en buena medida en la introducción de un esquema dinámico: el de la aspiración al vuelo, el de la distancia o cercanía entre el cielo y la tierra. Gilbert Durand considera una tendencia universal el hecho de que, en su interpretación simbólica, el pájaro rara vez es «encarado como un animal sino como un accesorio del ala [...]. El pájaro es desanimalizado, en beneficio de la función» ${ }^{64}$. El pájaro tiende a asociarse así a un simbolismo ascensional, a mecanismos simbólicos de sublimación de las fuerzas instintivas ${ }^{65}$.

Sin embargo, las aves de Gamoneda se resisten a este proceso de desanimalización. Revelan por lo general un vínculo con lo terrestre. Son pájaros que hablan con frecuencia de dolor, de desconcierto, de miedo, por lo que no faltan las referencias a cantos estridentes, a apariciones fugaces, a bandadas de aves que en ocasiones sugieren un gesto amenazante en la confusión que introducen: «¿Gritan aún en el relente aquellos pájaros sin descanso?» ${ }^{66}$, «Era un tiempo equivocado de pájaros?» ${ }^{67}$, « Gimen aún los pájaros? Todo está ensangrentado» ${ }^{68}$, «un país donde los pájaros se suicidan al amanecer» ${ }^{69} \ldots$ No se trata de un olvido del simbolismo tradicional del ave sino más bien de una tensión que se establece entre el pájaro como criatura literaria, emblema de la doble sublimación que representan el vuelo y el canto, y el pájaro como animal.

Ello se muestra con especial evidencia en el ave que con mayor frecuencia encontramos representada en estos poemas: las palomas. En nuestra tradición literaria, es esta una de las aves que con mayor frecuencia es sometida a un proceso de idealización. La paloma, símbolo de Venus y del eros sublimado en el paganismo grecolatino, es en la tradición cristiana el símbolo del Espíritu Santo pero también de la pureza y de la concordia tanto entre los seres humanos entre sí como, en el mito de Noé, entre el hombre y la divinidad ${ }^{70}$. En Gamoneda, sin embargo, parece invertirse este proceso de desanimalización. A ello no es ajeno el hecho de que, en la memoria del poeta, las palomas son menos símbolos convencionales que los seres de carne y hueso que poblaban el palomar al que, siendo niño, subió en más de una ocasión: a ello hace alusión un poema de Arden las pérdidas, que evoca «los

${ }^{64}$ G. Durand, Las estructuras antropológicas del imaginario, op. cit., 136.

${ }^{65}$ G. Bachelard (1980), El aire y los sueños. Ensayo sobre la imaginación del movimiento, 85-115; J. Chevalier y A. Gheerbrant, Diccionario de los símbolos, op. cit., 154-158; G. Durand, Las estructuras antropológicas del imaginario, op. cit., 136-139.

${ }^{66}$ A. Gamoneda, Esta luz, op. cit., 205.

${ }^{67}$ Ibid., 246.

${ }^{68}$ Ibid., 248.

${ }^{69}$ Ibid., 250.

${ }^{70}$ L. Monreal y Tejada, Iconografía del Cristianismo, op. cit., 528-529; J. Chevalier y A. Gheerbrant, Diccionario de los símbolos, op. cit., 796-797. 
desvanes habitados por palomas cuyas alas tiemblas entre tinieblas y cristales», «los desvanes de la infancia ${ }^{71}$. En ese sentido la paloma podría evocar la imposibilidad de hacer compatibles los recuerdos de un niño de posguerra con el mito de la pureza y la inocencia infantiles que nos ha legado la tradición literaria. Desde luego, la asociación de la paloma con la niñez es evidente en textos como este de Descripción de la mentira: «De los desvanes baja un clamor de palomas. Es el sonido de la infancia ${ }^{72}$. El simbolismo de la paloma en Gamoneda y sobre todo su renuencia a la idealización parece ir de la mano de una vivencia de la infancia radicalmente impura, lejos de todo mito de la Edad de Oro (a este respecto resulta especialmente iluminadora la lectura de Un armario lleno de sombra, libro en el que la niñez oscila entre el territorio mítico de una mirada inaugural sobre la existencia y la desmitificación de una época infantil que transcurre durante los años negros de la primera posguerra y el primer franquismo). De hecho, no deja de resultar significativo que una de las escasas ocasiones en las que la paloma parece asociarse al simbolismo tradicional sea en Cecilia, precisamente el libro de Gamoneda en el que el poeta encuentra en la infancia (no en la propia, sino en la de la nieta) un eco mítico del paraíso perdido:

Eres como la paloma que roza la tierra y se levanta y se aleja en la luz.

Tú atraviesas un resplandor

y yo te amo desde lejos ${ }^{73}$.

Frente a la imagen sublimada de la niña transformada en paloma, la escritura de Gamoneda nos asalta más a menudo con «palomas negras» ${ }^{74}$, con la «paloma impura ${ }^{75}$ que viene despacio al reino de la enfermedad y de la muerte. El yo lírico se siente compañero de «la soledad de las palomas extraviadas en la eternidad» ${ }^{76}$. La distancia que se establece con el simbolismo tradicional hace que la paloma puede asociarse incluso con la hipocresía, con la falsa apariencia de pureza: «Madre indistinta, líbrame de quien se oculta entre palomas, cubre mi rostro, sálvame del viernes» ${ }^{77}$ (no es improbable que esta alusión encierre una crítica a los representantes de la religiosidad tradicional, si la imagen encierra, como sospecho, un eco del consejo evangélico que conmina a los discípulos a ser astutos como serpientes y mansos como palomas).

Los valores tradicionales de la paloma son así cuestionados en la relectura que hace el poeta, pero no borrados. Precisamente porque el lector ve turbada la lectura tradicional del símbolo, se ve obligado a comparar las imágenes novedosas con las de la tradición. Así, estas palomas impuras parecen reflejar, de forma negativa, todos los mitos consoladores (Dios, la infancia idealizada, la eternidad...) que buscan eufemizar la muerte. Al insistir en el elemento terrestre, carnal, animal del

\footnotetext{
${ }^{71}$ A. Gamoneda, Esta luz, op. cit., 417.

72 Ibid., 209.

73 Ibid., 487.

${ }^{74}$ Ibid., 313.

${ }^{75}$ Ibid., 373.

${ }^{76}$ Ibid., 345.

${ }^{77}$ Ibid., 246.
} 
ave (así, por ejemplo en la asociación con los excrementos: «en los desvanes, augurios sobre excrementos de palomas» ${ }^{78}$ ), Gamoneda vuelve a mostrarnos su predilección por una «poética de la impureza», por usar la acertada expresión de Jordi Doce ${ }^{79}$. Si la mirada humana proyecta sobre el ave su deseo de trascender, a través del vuelo, su realidad terrestre, estos poemas obligan una y otra vez a reconocer que el mismo destino mortal les espera a los cuerpos humanos y a los cuerpos de las bestias. El impulso ascensional se resuelve en caída, en la constatación del abismo.

En esa dialéctica entre el vuelo y la caída, entre el cielo y la tierra, no sorprende que abunden, en los poemas de Gamoneda, presencias inequívocamente terrestres como son las serpientes y los insectos (el vuelo del insecto no puede, en el imaginario del poeta, borrar su parentesco con lo subterráneo, con el mundo de lo oscuro, de los muertos). En el Libro de los venenos, abundan por supuesto las referencias a ofidios venenosos. Sin embargo, en los poemas de Gamoneda son presencias más ambiguas, a la vez fascinantes y peligrosas: «Siento las oraciones, su lentitud, como serpientes bellísimas que pasaran sobre mi corazón» ${ }^{80}$, «Rosas, serpientes y cucharas eran bellas mientras permanecían en sus manos» ${ }^{81}$. De una manera más plástica que en las referencias génericas a los animales invisibles, las serpientes parecen situarse entre lo visible y lo que no se deja contemplar: sus refugios subterráneos, su movimiento ágil y silencioso... lo emparenta con esas otras presencias animales (incluidos los pájaros que pasan sin dejarse ver o cantan desde una espesura) que nos alertan sobre el aspecto enigmático de la realidad. Su belleza parece en ocasiones un eufemismo de la muerte, pero, como todos los eufemismos, se siente demasiado cercana la amenaza de la palabra tabú.

Sin pretender agotar su simbolismo en una única dirección, lo cierto es que la vinculación entre los insectos y la muerte es frecuente en Gamoneda. Numerosas imágenes parecen evocar el recuerdo de insectos (en especial, hormigas) que acuden a devorar la carne enferma o el cadáver del animal: «En cualquier caso: tengo miedo: los insectos vienen a mi corazón» ${ }^{82}$, «Mas las hormigas se dirigen hacia tus llagas y allí procrean sin descanso» ${ }^{83}$, «vi las locas hormigas sobre algodones ensangrentados ${ }^{84}$. Evidentemente, la fuerza simbólica de la imagen no procede únicamente de lo biográfico, ya que las asociaciones frecuentemente negativas que despiertan los insectos no son exclusivas de nuestro poeta. Recordemos, por ejemplo, la imagen surrealista concebida por Buñuel y Dalí en Un perro andaluz, donde uno de los personajes ve salir hormigas de una herida abierta en su mano, o la nada inusual reacción psicológica ante el insecto como algo repulsivo, que aparece tanto en grandes obras literarias, como la Metamorfosis de Kafka, como en los productos más toscos del cine de terror. Con todo, resulta significativo que en Un armario lleno de sombra, al evocar la exhumación de los huesos de su padre en 1945, el escritor evoque la presencia de unos insectos: «Vivos, entre la

\footnotetext{
78 Ibid., 473.

79 J. Doce (2008), «Lápidas, himnos, estaciones. El poema en prosa en Antonio Gamoneda, Geoffrey Hill y Seamus Heaney», Ínsula, 29.

${ }^{80}$ A. Gamoneda, Esta luz, op. cit., 261.

${ }^{81}$ Ibid., 322.

${ }^{82}$ Ibid., 470.

${ }^{83}$ Ibid., 230.

${ }^{84}$ Ibid., 272.
} 
tierra y los restos de mi padre que apuñaba, aparecieron unos pequeños bichos [...] Necesariamente aquellos bichos se alimentarían de los despojos negros y esponjosos de mi padre y habrían de ser animales ciegos» ${ }^{85}$

Asociados con frecuencia con el trabajo de la muerte, con la imagen del movimiento agitado, con el «bullicio de la larva», de la «agitación hormigueante, bullente o caótica» ${ }^{86}$, los insectos se vinculan a un movimiento amenazante, errático o ciego en apariencia (basta con contemplar un hormiguero) pero que parece encerrar un propósito bien determinado: «Oyes la destrucción de la madera (los termes ciegos en su venas), ves las agujas y los armarios llenos de sombra ${ }^{87}$. Sin embargo, el insecto no es solo una presencia hostil. Los insectos son obreros de la muerte pero también de la vida, que nace de la descomposición: «Mierda y amor bajo la luz terrestre. Yo abandono mis venas a la fecundidad de las semillas negras y mi corazón a los insectos» ${ }^{88}$. Simbolizan así el aspecto monstruoso pero a la vez fecundo de una vida, que no deja de crear y de destruir formas.

Entre la tierra y el cielo, no hemos agotado ni mucho menos el bestiario de la imaginación del poeta. No faltan, por supuesto, los animales domésticos: perros que pueden ser amenazantes pero que más a menudo evocan la carne menesterosa y débil, gallinas que revolotean alrededor de animales muertos, asnos de mirada blanca, caballos picassianos ajenos a toda épica pero que parecen compartir con el ser humano una extraña solidaridad en el dolor...

En la reiterada presencia de las bestias percibimos a la vez la familiaridad entre el animal y el hombre, que comparte con las bestias un mismo destino mortal, y la extrañeza que despierta la presencia muda de otro ser. La mirada poética experimenta la perplejidad ante una vida que da a luz multitud de criaturas para luego sumergirlas de nuevo en el seno de la inexistencia. La poesía de Gamoneda tiene algo así de grito animal, de bestia perseguida que aúlla ante un cazador invisible y, sin embargo, revela una mirada profundamente humana, la de la piedad que no renuncia a nombrar, a cuidar la vida vulnerable y en tantas ocasiones vulnerada.

\section{Referencias bibliográficas}

ADORnO, Theodor Wiesengrund, Teoría estética. Obra completa, 7, Madrid, Akal, 2004.

Agudo, Marta (ed.), «Somos únicamente palabras. Antonio Gamoneda en conversación», Quimera, núm. 275 (octubre de 2006), 26-33.

BACHELARD, Gaston, El aire y los sueños. Ensayo sobre la imaginación del movimiento, México D.F., Fondo de Cultura Económica, 1980.

BenJAMIN, Walter, Obras, libro I/ vol. 1, Madrid, Abada, 2007.

BLESA, Túa, «Sombras de luz», Ínsula, núm. 736 (abril de 2008).

BROCH, Hermann, La muerte de Virgilio, Madrid, Alianza, 2007.

\footnotetext{
${ }^{85}$ A. Gamoneda, Un armario lleno de sombra, op. cit., 232.

${ }^{86}$ G. Durand, Las estructuras antropológicas del imaginario, op. cit., 77-78.

${ }^{87}$ A. Gamoneda, Esta luz, op. cit., 391.

${ }^{88}$ Ibid., 467.
} 
CASAdO, Miguel, «El curso de la edad», en A. Gamoneda, Esta luz. Poesía reunida (1947-2004), Barcelona, Galaxia Gutenberg-Círculo de Lectores, 2004.

Chevalier, Jean y Gheerbrant, Alain, Diccionario de los símbolos, Barcelona, Herder, 1999.

CIRLot, Juan Eduardo, Diccionario de símbolos, Madrid, Siruela, 2000.

DoCE, Jordi, «Lápidas, himnos, estaciones. El poema en prosa en Antonio Gamoneda, Geoffrey Hill y Seamus Heaney», Ínsula, núm. 736 (abril de 2008).

DURAND, Gilbert, Las estructuras antropológicas de lo imaginario. Introducción a la arquetipología general, Madrid, Fondo de Cultura Económica, 2005.

FOUCAUlt, Michel, Las palabras y las cosas. Una arqueología de las ciencias humanas, Madrid, Siglo XXI, 2009.

GamonedA, Antonio, El cuerpo de los símbolos, Madrid, Huerga \& Fierro, 1997.

— Esta luz. Poesía reunida (1947-2004), Barcelona, Galaxia Gutenberg-Círculo de Lectores, 2004.

—_, Un armario lleno de sombra, Barcelona, Galaxia Gutenberg-Círculo de Lectores, 2009.

_ Libro de los venenos, Madrid, Siruela, 1997.

GómEZ TORÉ, José Luis «Antonio Gamoneda: palabra corporal, poesía del cuerpo», Cuadernos del Minotauro, núm. 2 (diciembre de 2005), 89-97.

— - «Un instante sin límites. Memoria y elegía en la escritura de Antonio Gamoneda», Quimera, núm. 275 (octubre de 2006), 40-45.

JunG, Carl Gustav, Los complejos y el inconsciente, Madrid, Alianza, 1992.

MAN de, Paul, Visión y ceguera: Ensayos sobre la retórica de la crítica contemporánea, Río Piedras, Editorial de la Universidad de Puerto Rico, 1991.

MogA, Eduardo, «Épica sensible. Saint-John Perse y Antonio Gamoneda», Quimera, núm. 275 (octubre de 2006), 50-53.

MonReal y TejadA, Luis, Iconografía del Cristianismo, Barcelona, Acantilado, 2000.

OTTO, Rudolf, Lo santo. Lo racional y lo irracional en la idea de Dios, Madrid, Alianza, 2005.

PAlOMo GarcíA, Carmen, «Caballos. Pequeña refutación al autor», Ínsula, núm. 736 (abril de 2008).

ZAmbrano, María, El hombre y lo divino, Madrid, Fondo de Cultura Económica, 2005. 